\title{
Auditions
}

\section{Sein oder Schein? \\ Paul Bekker's "Mirror Image" and the Ethical Voice of Humane Opera}

\section{\{NANETTE NIELSEN\}}

One of the most important music critics of the early twentieth century, Paul Eugen Max Bekker was born in Berlin on September 11, 1882, to a tailor and a seamstress. After a career as a violinist and a short stint as a musical director, he began his journalistic profession in 1906. He initially worked for the Berliner Neueste Nachrichten and the Berliner Allgemeine Zeitung. In 1911, his book on Beethoven was published and was very well received. This earned him the position, beginning in that year, of music critic at the Frankfurter Zeitung: one of the first such positions in Germany. ${ }^{1}$ As a critic and theorist, Bekker produced more than thirty books, along with numerous other publications, including Das deutsche Musikleben (1916), Franz Schreker, Studie und Kritik der modernen Oper (1919), Gustav Mahlers Sinfonien (1921), and Wagner, das Leben im Werke (1924). As Intendant in Kassel (1925-27) and Wiesbaden (1927-32), he was responsible for many performances and produced several operas, including Krenek's Jonny spielt auf, Schreker's Der singende Teufel, and Weill's Die Bürgschaft. Bekker left Germany in 1933 and lived in New York, where he was a critic for the New Yorker Staatszeitung, from 1934 until his untimely death on March 7, 1937. Only a handful of his books have appeared in English translation, and many of his theories of music's role in society have yet to be introduced to non-German readers. ${ }^{2}$

In a letter of August 24, 1929 to his close friend and colleague Leo Kestenberg, ${ }^{3}$ Bekker commented on the link between theory and practice in his work: if, as a writer, he had been in danger of becoming wholly lost in abstraction, his theater work had put him in touch with concrete reality. ${ }^{4}$ Although his practical commitment necessitated a retreat from active engagement as a critic, Bekker described this "silence" as an "inner gathering together [of experience]" [inneres Ansammeln], and believed that he was able instead to offer something unique in terms of performance and staging. His career as Intendant at Kassel and Wiesbaden offered an opportunity to turn into practice his theory of music's power to shape society. When formulating his ideals for operatic production, Bekker expressed a wish to reach more deeply than his contemporaries, to stage opera according to what he

The Opera Quarterly Vol. 23, No. 2-3, pp. 295-310; doi: 10.1093/oq/kbno42 Advance Access publication on January 9, 2009 (C) The Author 2009. Published by Oxford University Press. All rights reserved. For permissions, please e-mail: journals.permissions@oxfordjournals.org. 
termed the inner laws of the work. He identified music as das Urelement der Oper to which all other elements are subordinated. ${ }^{5}$ This notion of music's centrality was an expression of his ethical concerns, which were already formulated in his groundbreaking book of 1916, Das deutsche Musikleben, and which continued in his ethical conception of "sound" [Klang] in his writings on music phenomenology in the 1920 s. It is by sustaining music as the central element of opera (and opera production) that its ethical force is enabled and maintained.

By emphasizing music as a singular basic impulse of what we might subsequently consider "ethical opera," rather than as an element equal to others within the Gesamtkunstwerk (according to his interpretation of Wagner), Bekker was participating in the post-Wagnerian project in the 1920s. By 1922, Bekker found that contemporary opera had moved beyond what he regarded as a Romantic tendency for the music to be dominated by drama and action. Emphasizing Wagner as the major advocate for the subjugation of music in opera, he suggested that in the early twentieth century music had begun to guide theatrical aspects. ${ }^{6}$

In 1924, Bekker published his well-known book on Wagner, presenting a reading of the composer's life and works in light of the aesthetic trend of expressionism. ${ }^{7}$ Among his other writings on Wagner is the article "Wagner und die Gegenwart" (Die Musik, 1930), ${ }^{8}$ in which he emphasized how contemporary musical life had turned against Romantic ideals on the basis of two issues: a wish to return to the music itself and reclaim its inherent "natural powers," and a demand for an objectivity achieved by turning away from the subjective focus on the Self of the composer (the Romantic Ich) and toward the object of art. The conceptual basis for both of these points can be extracted from Bekker's Wagner monograph, in which he describes in detail the Romantic preference for emotional expression in music. In his discussion, the "Will to Expression," which makes subjectivity the basis of art, is contrasted with the classical era's balance between form and expression. The Romantic approach had also been a development away from the conception of music as a "natural acoustic phenomenon" toward an idea of music as "symbolically significant sound." 9 In Bekker's account of Wagner and the "Will to Expression," he points to how music is no longer central and "in charge," but determined by emotion:

Sound in itself is inexpressive; it is a natural fact, not a symbol, and it assumes form in accordance with the natural laws of its substance. Sound as expression, on the other hand, is simply the vehicle of something other than sound, and is shaped in servitude to the emotion the artist seeks to express. The will to display a nontonal emotion by means of tone now determines the shape of the sound-organism, and thereby conditions the character of the creative impulse itself, which ceases to be a distinctively musical impulse, springing up spontaneously, forcing an outlet and carving for itself the channel of musical form, and becomes instead an emotional impulse, which makes use of sound as a means of expression. ${ }^{10}$ 
It was Kestenberg who in 1931 made a link between Bekker and Wagner that is of particular interest for this issue on the Ring and the selected translation. In the preface to Bekker's book Das Operntheater, Kestenberg draws a connection between Bekker's project of organizing society via the power of music in Das deutsche Musikleben (discussed below) and Wagner's 1849 “Entwurf zur Organisation eines deutschen Nationaltheaters."11 As is well known, Wagner's article was written in the same spirit as his Zürich essays (1849-51), during a period in which he still believed strongly in social and cultural reform, despite the futile outcome of the 1848-49 revolutions. And (as Wagner scholars will recognize), the aesthetics that Wagner theorized during these years was to find particular expression in the Ring, which he was then working on. Kestenberg's comparison between Bekker and Wagner is apt in that by the time Bekker wrote his letter to himself in 1932, he had become disappointed by the failure of Weimar society to progress according to his idealistic plans of 1916. Nevertheless, it was through opera and his focus on "voice" that Bekker again formulated a potential means to cultural renewal. But as with Wagner's social ideals for the Gesamtkunstwerk, Bekker's utopian plan to restore unity to a fragmented Weimar society was also not to be carried out via the special field of opera, and therefore a gap remained between theory and practice.

\section{"To the Mirror IMAge"}

Bekker's letter “To the Mirror Image” displays what we might cryptically call a voice within a voice within a voice. In this first English translation of his letter to himself from his 1932 book Briefe an zeitgenössische Musiker (Letters to Contemporary Musicians), ${ }^{12}$ we are faced with a remarkably personal text that presents Bekker's critical voice in a manner rather unusual for him. One challenge of this text is posed by our general unfamiliarity with the thoughts of this Weimar critic. At the same time, it is also unique within Bekker's massive output, spanning more than thirty years. ${ }^{13}$ "To the Mirror Image" is a voice within a voice because we are granted an opportunity to listen to a somewhat subjective statement from an otherwise predominantly objective and detached writer. Given the message that Bekker communicates in this text, however, his decision to adopt a more personal writing style is not surprising: he attempts to get beyond "appearances" [Schein] in order to reach the essence of "being" [Sein]; this is accomplished by his deliberate separation from his own "mirror image." The performative aspect of this exercise leads to the distinction between who Bekker believes he is in the eyes of the public and who he really is. As the text reveals, the two images remain fundamentally irreconcilable.

At the same time that he makes this subjective statement, Bekker never loses sight of its wider ramifications. "To the Mirror Image" is a voice within a voice 
within a voice because at the center of his concern is the "human singing voice" of opera, and the extent to which a focus on the operatic voice would constitute a renewed focus on humanity in general. Bekker's ideas about voice featured frequently in the criticisms presented in Briefe. He calls the voice one of the strongest powers that human beings possess, considering it the most compelling artistic measure as well as a crucial "ethical-aesthetic" norm for the creation of music. ${ }^{14}$ He felt it was a "cardinal sin" that contemporary opera composers were unable to understand the human singing voice, and therefore unable to write for it. ${ }^{15}$ Throughout the book, the link between demands for a focus on voice in opera (production as well as creation) and a renewed understanding of humanity is unmistakable: only if the human being is at the center of artistic creation will art be a "truthful" and "honest" enterprise, and for opera this means a focus on the human voice. Aesthetically, this text offers the reader a glimpse of Bekker's contribution to developments in modern opera. Ethically, he partakes in a critical exercise not entirely dissimilar to the warning against the alienation of music from man that Adorno expressed in his essay "On the Social Situation in Music," published in the same year. ${ }^{16}$

The present introduction focuses in particular on sociological and ethical aspects of Bekker's thought, and situates "To the Mirror Image" within his oeuvre, rather than within wider political, cultural, and historical contexts. Although this commentary will by no means uncover the multiple layers of the translated text it will, I hope, nevertheless aid an understanding of this fascinating albeit obscure source.

\section{BRIEFE AN ZEITGENÖSSISCHE MUSIKER}

Published in 1932, Briefe an zeitgenössische Musiker enters the critical scene at the very end of the increasingly politically fragmented Weimar period, before the Nazi iron fist finally gained its grip in 1933. Given the relevance of the political and economic unrest to the musical milieu, it is not surprising that we can detect in Bekker's tone a dissatisfaction with Weimar society and disillusionment with its development.

Briefe was the last book by Bekker to be published in Germany. As its title suggests, it is a collection of (fictitious) letters to musicians then working in Germany. ${ }^{17}$ Each of the letters includes various elements of criticism and praise. For example, Bekker advises Kurt Weill against too much political engagement; he criticizes Ernst Krenek for being too concerned with worldly matters, and also accuses him of thinking and reflecting too much instead of focusing on making music; and finally, as directly stated in "To the Mirror Image," he praises Richard Strauss as the only composer who had succeeded in "bringing art and life together," who managed to put at the center of his concern the "one measure" of 
the truth of humanity, namely man himself. It might be useful, when reading Bekker's comment about Strauss in “To the Mirror Image," to keep in mind how this has links to his music sociology. In the Briefe letter to Strauss, Bekker makes a close connection between the development of Strauss's music and World War I: Bekker considered Strauss's new aesthetic direction (Josephslegende, Alpensinfonie, and Frau ohne Schatten) to be related directly to the turmoil of contemporary society. ${ }^{18}$ To paraphrase Andreas Eichhorn, he viewed the stagnation of Strauss's artistic production as an aesthetic correlation to the social situation in $1914 .{ }^{19}$ In other words, Strauss's ability to "bring art and life together" suffered when the world around him became too fragmented for this kind of unity.

It was also during the course of World War I that Das deutsche Musikleben (1916) appeared. This was Bekker's major contribution to the development of music sociology, and some of the various titles that were considered by him and the publisher Bernhard Schuster are clear indications of their understanding of the book's pertinence to the contemporary political situation: Das Musikleben, Musik und Gesellschaft, Musik als Gesellschaftsmacht, and Soziales Musikleben (Bekker); and Musik in Not, Der Musiker und seine Stellung, and Musik, Gesellschaft, Kritik (Schuster). When they settled for Das deutsche Musikleben, Bekker suggested that the subtitle should be Ein Kriegsbuch (but Schuster did not agree). ${ }^{20}$ A brief summary of the key points made in this book will give the reader an idea of Bekker's sociological thought and the extent to which he held, at this point in time, high hopes for a reshaping of German society via music.

\section{DAs deUtsche Musikleben}

Central to Bekker's music sociology is his theory of musical form and the related idea that music acts as a "socially formative force." Although this concept of music's gesellschaftsbildende Kraft was not employed directly until Die Sinfonie von Beethoven bis Mahler (1918), we can extract its meaning from formulations in Das deutsche Musikleben. ${ }^{21}$ In this text, Bekker attempts to define a sociologically grounded musical aesthetics and, in doing so, employs a sociological conception of form, which he describes as a common denominator or "product" shared by society, musician, and criticism. For Bekker, "The Society," “The Musician," and "Criticism" are the three "creative elements" that together, mutually conditioned, constitute the musical form. This concept of form derives first of all from his understanding of the sound patterns [Klangbilde] of a composition. Conceived on their own, the sound patterns, for the musician, are the material of the written music, which then turns into form by being perceived by society. In his words, "the form is not quite simply material: it is material which has been perceived."22 Form develops out of the material and takes shape via society. 
The following quotation clarifies Bekker's explanation of the close relationship between music and society. We can recognize here issues that Adorno was later to develop (such as the sociological relationship between musical material and its perception), and also the distancing from a formalist aesthetics that would seek to view music apart from its social origins: "The formal laws of the material in general do not depend upon the organic laws within the material. They are the results of the interaction between the material and the ability of the society to perceive: they are sociologically conditioned. The sound image is an image of society transformed into tonal material, not an aesthetic, but a sociological sound-symbol."23

For Bekker art is in itself a critique of society. ${ }^{24}$ Music occupies a special place within art because it has no other form (in Bekker's sense of the word) than that achieved through its interaction with its audience. The form of music is thus both a product and an expression of the "living will of society" [des lebendigen Gesellschaftswillens]. By understanding the spirit of the time and expressing it through music, by what Bekker names a "klangliches Symbol" ("sound-symbol"), the musician produces a work of art that is conditioned by both the individual (the musician) and society. ${ }^{25}$ The ability of society to perceive ensures that music occupies an active place in the world. Significantly, Bekker views criticism - the third element of musical form after the musician and society-as having a threefold role in the creation of the musical work. The first task of criticism is to grasp the form of the music through its creative elements (society and musician) and to make clear what the form-concept entails and demands. The second task is to determine the contemporary conditions within which the music has been created, that is, to explain and evaluate the relationship between musician and society in their historical surroundings. The third task is to clarify the transformation of the form of the musical work as the work engages through time with society and is perceived by this society. ${ }^{26}$

Bekker provides the following summary: "Society, musician, and criticism constitute the three elements of musical form: society and musician as the creative forming powers, and criticism as the principle of cognition which brings to clear conceptual intuition the form as an appearance of society through a synthesis of these creative forces." ${ }^{27}$ Through its interaction and active engagement with society, musical form makes music function as a socially formative force [gesellschaftsbildende Kraft]. ${ }^{28}$ The positive sociological project undertaken in this book is expressed most strongly in the conclusion, where Bekker points forward to a brighter future. He emphasizes how an understanding of his form-concept requires the recognition that contemporary music is an expression of its time. Every age has its own musical form. Consequently, Bekker suggests what 
social demands ought to be placed on contemporary music, stressing its inherently social function and its power to shape and change society. Given its ethical-creative power, the role of music is not to provide enjoyment or beauty, but actively to participate in and reflect contemporary thought, and to inspire an ideal structure for society:

Our music must become contemporary art. Contemporary art in the sense of a creative shaping of new ideas of life, ideas that-born of necessity-become the basis of a new vision of existence. By taking over such a task, music steps outside the narrow circle of artistic means of making existence beautiful. Music becomes a power of organising the people, an expression of the aesthetic collective will, a creative force within our social form of appearance. When turning to the collective, it needs the active participation of this collective. Winning this for it is the task of our time. Its [our time's] mission is to create in its music the living monument of itself. ${ }^{29}$

By the mid-1920s Bekker had deemphasized his sociological approach, but had not thereby diminished the ethical impetus of his writings. As he turned to music phenomenology, he continued to account for music's ethical potency through a language filled with "natural concepts" (e.g., Kraft and Klang), as we can also see in "To the Mirror Image." 30

\section{Music, Politics, and the Ethics of Voice}

If Das deutsche Musikleben contains high hopes for the future musical and cultural life of Germany, one has the distinct sense when reading "To the Mirror Image" that by 1932 Bekker had become disillusioned with the society in which he lived and worked. In the following I comment on tensions between ethics and politics in Bekker's work, and aim to show how his disenchantment was expressed in some of his central writings on music, culminating with the specific reference to the relationship between voice and humanity that we find in his writings on opera towards the end of his career in Germany. Briefe is bordered by Bekker's two major works on opera resulting from his practical work at Kassel and Wiesbaden, Das Operntheater (1931) and Wandlungen der Oper (1934), in which the notion of voice is equally central.

Despite his leftist, democratic leanings, which might have led us to believe that he had a specific party agenda in his writings, Bekker had no intention of establishing such a precise political purpose for music. Amidst the turmoil and propaganda of World War I, however, Bekker viewed politics as potentially subsumed under ethics; whereas his ethics could not be reduced to politics, politics could certainly occupy a place within ethics. Evidence for this can be found in the 
1917 article "Künstler als Politiker" ("Artist as Politician”), in which he explores the relationship between art and politics. ${ }^{31}$ After reflecting on Heine's view of the artist as nonpolitical by nature, ${ }^{32}$ he turns to the contemporary situation and argues that the concept of the political has changed over time, and that therefore a reconsideration of the artist's role is required. More than ever, Bekker argues, politics entails gathering as much collective power and activating as many people (including artists) as possible. This view is clearly based on his democratic ideals, but more significantly, Bekker requires that the artist employ his or her creative powers in order to carry out this process of unification, thereby linking his understanding of politics and the political demands on the artist with the ethical ideas that emerged with his form-concept in 1916.33 What underlies the argument for political engagement, then, is the idea that ethics, as expressed in the conception of unifying creative powers, can be useful in a political sense-to engage and influence the masses.

As with his form-concept, Bekker's formulations become circular: not only does art express itself within a society that it subsequently helps to shape, it also expresses the very society from which it is born. The artist gains from the engagement with politics (with the inner needs of society) the very power with which he or she shapes this society: when engaging with politics, art is strengthened. In Bekker's words, by becoming politically active, the artist

does not thereby become impoverished, rather he can bring a new force to the expanding field of political effort: the force of the creative idea. This force will flow through him with tenfold power as he learns to understand how to recognize the deepest suffering of his people from their most basic and daily needs, in order thereby to find the root from which alone can arise a truly great, all-embracing and universal art. ${ }^{34}$

The relationship between art and politics should not be established in order to achieve political power or engage in party politics, but rather to activate and inspire the inner creative power that art is able to provide.

However, although it is possible to include politics within ethics at this stage in Bekker's work, in his later writings he increasingly expresses a wish for a separation between politics and music. For example, in 1932, he warns against a deterioration of the quality of performances, "insofar as the value of the performance is precisely no longer measured according to its quality, but according to its political functionalism." 35 In 1931, he devotes the last two chapters of Das Operntheater to a critique of the contemporary political structure and its influence upon opera, which at this point in time was suffering from a lack of funds. ${ }^{36}$ Bekker believes opera had been let down by a society which did not recognize the importance of opera's "inner organic laws" and productive power. ${ }^{37}$ And the impact that the turbulent public life in Germany at this point had on 
music-making is voiced in his warning against how politics, "which calls itself culture-politics," was in danger of drowning in party politics. ${ }^{38}$

Bekker's wish to avoid the influence of party politics on music, and his reluctance to allow music to function according to any particular political program, was already voiced in connection with his practical opera work at both Kassel and Wiesbaden. As retiring Intendant for Kassel, he was approached by the Kasseler Tageblatt to write a brief article on what, in his opinion, would be most beneficial for Kassel in 1927. His first suggestion is that his replacement should be someone who would be equally welcomed by all political parties, organizations, and "beer-halls." 39 Later, as Intendant for Wiesbaden in 1931, Bekker wrote, in response to a request from the Rheinische Volkszeitung, a public statement on behalf of the theater in which he again (if with greater emphasis) turns to the issue of politics, as part of a discussion of the freedom of both criticism and the theater:

With regard to this freedom of the theater, I count, above all personal things, the freedom from party politics. Like any other big business, the theater regards its members as people who may be associated with any party. On stage, we are neither National Socialists, nor Social Democrats or Centrum people. If we show works which are appropriate for this or that party, we do not show them out of bias towards any particular party: we show them because they are documents of the general intellectual and public life. Everyone can take from this what does or does not suit him—all we do is live up to our duty to show the works and thereby to present them for discussion. ${ }^{40}$

One way to explain the development of Bekker's understanding of the relationship between politics and music would be to point to a discrepancy between the ideal and the real. If his 1916 sociological ideas about music offered a means by which musical form could assist in shaping an ideal structure for society (ideas subsequently elaborated in his writings on opera and opera aesthetics), by the mid-twenties he realized that Weimar society was not developing according to this ideal structure. Indeed, by 1929, he would comment that Das deutsche Musikleben had been too idealistic, his hopes "all too fantastic." ${ }^{11}$ The separation of his "ethical politics" (as described in 1917) from the party politics that had come to dominate the contemporary scene is an indication of his growing disappointment. In the light of his mounting frustration with the political structure of German society, it is instructive to explore Bekker's notion of the human voice in opera, and how it became a particularly ethically laden concept-increasingly so throughout the 1920s, and especially towards the end of his career at Wiesbaden, as in "To the Mirror Image." It is through his concept of voice that he makes a final attempt to suggest a way forward for operatic (and social) renewal. 
Some of the ideas behind Bekker's later theorization of the voice were initially outlined in the unpublished talk "Die Opernszene der Romantik" (1923). ${ }^{42}$ As part of a discussion of the potential unity of staging and music in opera, while distinguishing between the visual and the audible he identifies the precise point where the two art forms of theater and opera meet, one that is situated both within the music and on the stage: the acting and singing human being. ${ }^{43}$ In a performance of opera, it is the singer who connects the apparently contrasting worlds of stage and music, and thus becomes the artistic "life-center" [das Lebenszentrum] of opera, and its aesthetic justification. He builds his argument in this article from the starting point of the singer, considering opera as a means by which the singer can be presented and engaged. ${ }^{44}$ Compared with later writings, where the concept of voice carries literal but also powerful metaphorical meanings, Bekker's description of the voice in this article is predominantly linked to concrete historical developments and stylistic categorizations in opera (such as the usage of particular voice types).

Two subsequent articles in which voice is a key theme, "Stimme und Gestalt" (1924) and "Die Neue Oper" (1925), also explain opera as an expression of the human voice and provide stylistic descriptions of its central role in the history of opera. ${ }^{45}$ In 1924 Bekker calls opera "the dramaturgy of voices," ${ }^{6}$ and in 1925 repeats the idea that opera is the means by which the singing human voice is "made possible." 47 What is crucial, however, and what distinguishes these two articles from the unpublished talk of 1923, is the way that the human voice has become increasingly central to his views on opera. The singing human being is described in 1925 as the "unchangeable aesthetic object of all opera." ${ }^{8} 8$ This leads Bekker to suggest that the only way the creation of a novel kind of opera can take place is through recognition of the potential of the human voice to express its own contemporaneity. He does not call for a reform of opera as such, but for a realization of the potential of the inner creative powers of opera that are present in the voice. Furthermore, the approach he recommends links the concept of voice directly to his form-concept and to the idea that musical creation springs from, and is an expression of, the "living will" of society:

In this new recognition of the voice in general, but particularly within the overall sphere of opera of all times and directions, lies the task of the productive conception. For the "new opera" is not that which comes to us from outside like a new fashion accessory, but what we see anew from the force of our view and put out from within. 49

Bekker emphasizes the close relation of voice to nature and the fact that voice is a natural phenomenon with natural properties. Thus, for example, the idea that the human voice is an unchangeable aesthetic object is based partly on the fact that male and female voices are unchangeable according to the rules of nature. ${ }^{50}$ 
Another example is his description of the voice as the only living and life-giving Urelement of opera; in other words, the voice is something inherently fundamental, ancient, and original. ${ }^{11}$ The reliance on nature, or a "natural vocabulary," as a way of explanation is not surprising, given his recurring references to nature when formulating the concept of musical form in 1916, as well as his interest in establishing a musical phenomenology. We can recognize the references to nature also in "To the Mirror Image." Similarly, allusions to nature in Wandlungen der Oper of 1934 provide his final comprehensive characterization of the human voice:

The singing human voice is the root from which the opera has sprouted and grown. It is the force that carries the opera forward. It is the power that ever anew leads it to completion, according to the mode in which the nature of the voice is perceived. From the voice arises the form [of opera]: it becomes physically perceptible in such shape as is dictated by the development of the voice. ${ }^{52}$

If in Bekker's earlier writings opera was considered to be the means by which the human voice could be expressed, by this stage it had become the end result: it is from the voice that opera grows. His conceptualization of the voice in 1934 still provided a focal point for concrete historical and stylistic analyses of opera: he sketches the history of styles of singing and compositional usages of the voice from Gluck and Mozart, through to Wagner, Verdi, and contemporary German opera. However, as in "To the Mirror Image," the 1934 portrayal also embraces metaphorical abstraction and offers a concept of voice in which it has achieved ultimate centrality. In addition to being the unchangeable aesthetic object of opera, the human singing voice becomes, crucially, its ethical subject. This can be deduced first of all from Bekker's assertion, in the first chapter of Wandlungen (entitled, like his earlier article, "Stimme und Gestalt," and devoted to the concept of voice), that "the singing voice is a direct expression of man himself." 53 Concluding the book with an expansion of his findings on the stylistic development of the voice in opera, he points to a final interpretative layer via which something meaningful from an investigation of opera can be deduced. Following from the recognition that the voice is essentially the human being, the meaning of the voice is ultimately "man himself." 54

In addition, Wandlungen der Oper offers a critique of contemporary Weimar society that is typical for Bekker's later writings. ${ }^{55}$ In the foreword, he makes clear how this publication, as a book on opera, is concerned with the troubled contemporary climate, in which "creative work" is confused with "mere activity" (in other words political activity) and "culture" is replaced by "propaganda." ${ }^{6} 6$ In order to rectify the current problems of society, he calls for an understanding of the "nature of man," and a focus on the human being as "the origin and goal of all art." 57 It is through the human singing voice that opera is inseparably connected with the 
nature of man. The end of the foreword not only bears witness to Bekker's ethical concerns, but it also emphasizes opera's role in a renewed understanding of a society in which individuality and individual creativity fare well, and are not subdued by a domineering and politically oriented collective:

It is on the basis of such an indissoluble bond between opera and the nature of man that the past must be understood, the present judged, and the future sensed. When once the recognition of this fact has penetrated, it may help, through the special field of opera, to establish firmly respect for man himself. For it will show that art is never the collective product of a group or community with a world-view, but that its existence always has been, is, and will be possible only where man as such is possible..$^{8}$

From this brief discussion of the interaction between Bekker's ethics and his views on contemporary operatic practice, we can conclude that it is within the concept of the human voice that ethics and aesthetics meet. In Bekker's writings, the ethical imperative of the production of art and music in Weimar society is to be understood in terms of the aesthetic life-form of opera and, in particular, the unchanging aesthetic object and ethical subject that is the human voice. Conversely, aesthetic expression as provided by music and opera is to be understood in terms of ethical enactment; it is from within the musical work itselfthe opera, the voice-that the living will of society grows. Thus, there is an ethical responsibility to make musical creation happen. With Bekker, the intersection of ethics and aesthetics works both ways, and we are left with an ethical aesthetics, as well as an aesthetic ethics.

In "To the Mirror Image," the above issues are reflected in Bekker's focus on man as the basic measure of all value, including musical and artistic value. He describes "the humane man" as detached from politics, and points to voice and a renewed focus on "man himself" as a path via which opera can revive itself. Art is capable of reflecting the power of humanity, but only if art emanates from humanity in the first place. For Bekker, opera should spring from what he calls the "absolutely real or natural pattern for man" in music: the human voice.

\section{NOTES}

Nanette Nielsen is a lecturer in music at the University of East Anglia. Her areas of research are music and philosophy, opera and music theater in the Weimar Republic, melodrama, and film music. She is currently preparing a monograph on the convergence of ethics and aesthetics in Paul Bekker's work as a critic and an opera producer. She is also a choral conductor and directs the UEA Chamber Choir, which she founded in 2007.
1. As Christopher Hailey puts it: "Eine der ersten Stellen im deutschen Musikleben" (Hailey, Paul Bekker/Franz Schreker: Briefwechsel, mit sämtlichen Kritiken Bekkers über Schreker [Aachen: Rimbaud, 1994], 10).

2. Beethoven (1911) was translated and adapted from the German by M. M. Bozman as Richard Wagner: His Life in His Work (New York: W. W. Norton, 1931); The Story of Music: An Historical Sketch of the Changes in Musical Form 
(New York: W. W. Norton, 1927); The Changing Opera (London: J. M. Dent, 1936); and The Story of the Orchestra (New York: W. W. Norton, 1936), first written in English, and later translated into German as Das Orchester (Kassel:

Bährenreiter-Verlag, 1989). Although the

literature on Bekker is still sparse, two important works have recently appeared (albeit in German): Vera Baur, Paul Bekker: Eine Untersuchung seiner Schriften zur Musik (Aachen, 1998), and Andreas Eichhorn, Paul Bekker-Facetten eines kritischen Geistes (Hildesheim, 2002).

3. Kestenberg (1882-1962) was musical adviser for the Prussian Ministry of Science, Culture, and Education from 1918, and in 1922 he became director of the music department of the Central Institute for Education and Teaching. He was the author of Musikerziehung und Musikpflege (Leipzig, 1921), which influenced all levels of music education, and drew explicitly on Bekker's Das deutsche Musikleben. The extensive correspondence between Bekker and Kestenberg can be found in the Bekker Collection, MSS50, Gilmore Music Library, Yale University.

4. "Als guter Freund und vorstehender Beobachter wissen Sie, dass ich als Schriftsteller an einen Punkt gelangt war, wo die Gefahr bestand, mich völlig in Abstraktion zu verlieren. Das Untertauchen in die praktische Arbeit war eine Selbsthilfe und musste kommen" (Bekker Collection, Folder $7 / 81,3)$. All translations are mine unless otherwise noted.

5. See Bekker, "Die Opernszene," Klang und Eros (Stuttgart: Deutsche Verlags-Anstalt, 1922), 141-66, 152; first published in the Frankfurter Zeitung 58, no. 232: 1-3, and no. 233: 1-2 (1913). "Die Opernszene" was Bekker's first attempt to write a longer, comprehensive work about the production of opera and its aesthetic basis. Nearly ten years later followed the (unpublished) talk, "Moderne Oper" (1922; Bekker Collection, Folder 45/595). For an extensive description of the role of music in opera, see Bekker, Das Operntheater (Leipzig: Quelle und Meyer, 1931).

6. See, for example, "Moderne Oper," where Bekker is keen to stress that he does not wish to display hostility [Anfeindung] towards or depreciation [Herabsetzung] of Wagner's views (6), but that he merely points out a natural development of opera. In general, it should be noted that he extracts from Wagner's writings the material that would support his own agenda. To be sure, Wagner's ideas on the status of music within the Gesamtkunstwerk have often been misunderstood in the popular and critical traditions of Wagner reception and scholarship. This is largely prompted by the complex nature of Wagner's own views, in addition to the changing emphases found in writings from different stages of his career. In spite of his critique of Wagner, Bekker may have recognized music's pre-eminence within the total art work. His emphasis in the book, however, is very much on the overall expressive aims of the music drama.

7. See Bekker, Wagner, das Leben im Werke (Stuttgart: Deutsche Verlags-Anstalt, 1924), in English translation as Bekker, Richard Wagner: His Life in His Work, trans. M. M. Bozman (London: J. M. Dent and Sons, 1931). As he comments in the preface to the book, Bekker considered the term Expressionism "one of the most popular in present-day critical terminology." It is worth noting that Bekker did not carry out an expressionist reading, but drew on Expressionism as "an idea" to support a historical interpretation of Wagner. Indeed, Bekker's antimetaphysical stance did not tally with expressionist aesthetics. See, for example, his very negative review of Ernst Bloch's Geist der Utopie (published in 1918 and widely considered an expressionist manifesto) in "Musik und Philosophie," Frankfurter Zeitung, Erstes Morgenblatt, April 6, 1919, 1-2.

8. See Bekker, "Wagner und die Gegenwart," Die Musik 23 (1930): 1-14. Further writings on Wagner include "Richard Wagners Briefe: Ein Beitrag zur Lebensgeschichte des Meisters, v. Dr. Wilhelm Altmann," Allgemeine Musik-Zeitung 1 (1906); "Mein Leben von Richard Wagner," Frankfurter Zeitung 55 (1911); "Wagners Briefe an Hans von Bülow," Frankfurter Zeitung 61 (1916); and "Der Weg zum Wagner Mythos," Die Musik 25 (1932).

9. Bekker, Richard Wagner: His Life in His Work (1931), 6-7.

10. Ibid., 7. Immediately following this quotation, Bekker reveals his distinction between "masculine, formative natures" and "feminine, emotional natures." This distinction can usefully inform our understanding of his somewhat cryptic reference to "woman" in the letter below.

11. Kestenberg quotes an extract from Wagner's text to substantiate his point: "In der theatralischen Kunst vereinigen sich, mit mehrer oder minderer Beteiligung, sämtliche Künste zu einem so unmittelbaren Eindruck auf die Öffentlichkeit, wie ihn keine der übrigen Künste für sich allein hervorzubringen vermag. Ihr Wesen ist Vergesellschaftung mit Bewahrung des vollsten Rechtes der Individualität" (quoted in Bekker, Das Operntheater [Leipzig: Quelle and Meyer, 1931]).

12. Briefe an zeitgenössische Musiker (Berlin-Schöneberg: Max Hesses Verlag, 1932).

13. Bekker published more than thirty books and hundreds of articles. For a detailed list of 
Bekker's writings, see Eichhorn, Paul BekkerFacetten eines kritischen Geistes (Hildesheim: Georg Olms Verlag, 2002), 673-736.

14. "Jeder Mensch hat gewisse Glaubenssätze, die er von Natur in sich trägt, und die ihm jede Erfahrung, auch die unfreundlichste, immer wieder bestätigt. So glaube ich an die beherrschende, gesetz- und gestaltgebende Kraft der menschlichen Stimme. Ich glaube an sie als eines der stärksten künstlerischen Regulative, die der Mensch in sich trägt. Ich glaube an ihre Macht als ethish-aesthetische Norm, überhaupt als an die Erscheinung, die für unsere Aesthetik der Musik ausserhalb jeder spekulativen Beimischung ebenso das Grundmass bildet, wie der sichtbare menschliche Körper für die Kunst der Plastik" (Bekker, "An den Opernsänger A... in B ...," Briefe, 163).

15. Ibid., 163.

16. Theodor W. Adorno, "On the Social Situation of Music," in Essays on Music, ed. Richard Leppert (London: University of California Press, 2002), 391-437. Much influenced by his music sociology, Adorno described Bekker as "the most intelligent music critic in Germany between the wars" (Adorno, Impromptus [Frankfurt, 1968], 84).

17. The recipients were (in order of presentation): Richard Strauss, Wilhelm Furtwängler, Paul Hindemith, Leo Kestenberg, Arnold Schönberg, Franz Schreker, Hans Pfitzner, Ernst Krenek, Kurt Weill, Heinz Tietjen, Artur Schnabel, the Opera Singer, the Operetta Composer, and the Mirror Image. The collection also included a letter to the publishers Bote and Bock.

18. See Bekker, Briefe (1932), 7-18.

19. See Eichhorn (2002), 167. Bekker's ambivalent and changing attitude toward Strauss cannot be covered adequately here. Only two years after Briefe, writing from the safe and critical distance of Paris (for the Pariser Tageblatt), Bekker would call Strauss a Hitlermanne. See Eichhorn, ed. "Geist unter dem Pferdeschwanz" Paul Bekker's Feuilletons aus dem Pariser Tageblatt, 1934-1936 (Saarbrücken, 2001), 95.

20. Taken from Eichhorn (2002), 164-65.

21. Das deutsche Musikleben was one of the first attempts to formulate a coherent music sociology. At the beginning of the century, Hermann Kretzschmar and Karl Storck had expressed central thoughts on the relation of sociology to music from which Bekker's ethical ideas sprang. Kretzschmar, for example, was inspired by the ancient Greek view on the relation of ethics to music and music's moral influence on the human mind. Storck emphasized music's social ability to unite people and inspire a unified society. See Vera
Baur, Paul Bekker, 8-18.

22. "Die Form ist also nicht Materie schlechthin: sie ist wahrgenommene Materie" (Bekker, Das deutsche Musikleben [1919], 3).

23. Ibid., 8: "Die Gestaltungsgesetze der Materie überhaupt beruhen nicht auf innerorganischen Gesetzen der Materie. Sie sind Ergebnisse der Wechselwirkung zwischen Materie und gesellschaftlichem

Wahrnehmungsvermögen: sie sind soziologish bedingt. Das Klangbild ist ein in Klangmaterie umgesetzes Gesellschaftsbild, kein aesthetisches, sondern ein soziologisches Klangsymbol."

24. Ibid., 12: "Kunst ist Gesellschaftskritik."

25. It is worth noting that although in this work Bekker supports his ideas by mentioning a number of composers, "musicians" [Musiker] refers first and foremost to the practicing musician, not to the composer. This is of course related to Bekker's investigative focus on the musical work as it relates to the Umwelt, its situation in the surrounding world; although the composer creates the musical material, performance provides the possibility to turn music into "form" and thereby occupy a place in the world. Bekker's later remark on the difference between the musician and the composer highlights further the importance of performance: "Musiker sein heisst Bildner sein. Bildner sein entspricht nicht der Tätigkeit des komponierens im heutigen Sinne, die meist nur ein Nachbilden ist, weil sie gegebene Muster Reproduziert. Bildner sein heisst Formen Schaffen. Nur die lebendige Form ist wahrhafte Form. Nur der sie kündet, ist der Musiker" (ibid., 165). See also Eichhorn, Paul Bekker, 185, where he comments on the fact that Bekker replaced certain concepts to suit his aesthetic/sociological points. Thus "Kunstwerk," "Komponist," "komponieren," are replaced with "Form," "Gestalter," "Musiker," "Bildner," and "gestalten."

26. The threefold task of criticism is outlined in Bekker, Das deutsche Musikleben, 169. These three elements certainly correspond to Bekker's own approach to music criticism. Regarding the third task, the word transformation is significant. Bekker deliberately chose this word over the word development because he wished to avoid making the judgment that musical form has progressed or improved. The form changes according to the time in which it is being perceived. For a discussion, see Bekker, The Story of Music: An Historical Sketch of the Changes in Musical Form (New York: W. W. Norton, 1927), 19-29.

27. Das deutscher Musikleben, 14: "So sind Gesellschaft, Musiker, Kritik die drei Elemente der musikalischen Form: Gesellschaft und Musiker als die schöpferisch gestaltenden Kräfte, 
Kritik als das Prinzip der Erkenntnis, das durch Synthese dieser schöpferischen Kräfte die Form als Gesellschaftserscheinung zur begrifflich klaren Anschauung bringt."

28. It is worth noting that Bekker's forceful language often defies concretization and logic. His form-concept, for example, remains circular, and he chooses freely between form as produced by society, and society as produced through form. From a practical perspective, however, this theoretical frailty does not weaken the core of his ethical project. For a brief critical analysis of some of the inconsistencies in Bekker's arguments, see Giselher Schubert, "Aspekte der Bekkerschen Musiksoziologie," International Review of Music Aesthetics and Sociology 1, no. 2 (December 1970), 179-86.

29. Das deutscher Musikleben, 236: "Unsere Musik muss Gegenwartskunst werden. Gegenwartskunst im Sinne schöpferischer Gestaltung neuer Lebensideen, Ideen, die, aus der Notwendigkeit geboren, zur Grundlage einer neuen Daseinsanschauung werden. Mit der Übernahme einer solchen Aufgabe tritt die Musik heraus aus dem engen Kreise artistischer Verschönerungsmittel des Daseins. Sie wird zu einer Macht der Volksorganisation, zum Ausdruck des ästhetischen Gesamtwillens, zur schöpferischen Kraft innerhalb unserer sozialen Erscheinungsform. An die Gesamtheit sich wendend, bedarf sie der tätigen Anteilnahme dieser Gesamtheit. Ihr diese zu gewinnen, ist die Aufgabe unserer Zeit. Sie ist berufen, in ihrer Musik das lebende Denkmal ihrer selbst zu schaffen." Bekker's "forceful" language has recently been discussed by Karen Painter in "Paul Bekker and an Aesthetics of Strength" in Symphonic aspirations: German music and politics, 1900-1945 (Cambridge, MA: Harvard University Press, 2007), 150-55.

30. See, for example, Bekker, "Klang und Eros: Brief in die Ferne," in Klang und Eros (Stuttgart: Deutsche Verlags-Anstalt, 1922); Von den Naturreichen des Klanges: Grundriss einer Phänomenologie der Musik (Stuttgart: Deutsche Verlags-Anstalt, 1925) and "Was ist Phänomenologie der Musik?" in Die Musik 17 , no. 4 (1925), 241-49.

31. First published in the Frankfurter Zeitung 62 (Nov. 1917), 1-2. In the following, I am referring to its republication in Kritische Zeitbilder (1921), $198-205$.

32. Ibid., 200.

33. Bekker's discussions of relationships between ethics, politics, and music already took shape a few years earlier in Beethoven (1911).

34. Bekker, "Künstler als Politiker," 205: "Wird daran nicht verarmen, er wird eine neue Kraft hineintragen in das sich ausweitende Gebiet der politischen Arbeit: die Kraft der schöpferischen Idee. Diese Kraft wird ihm verzehnfacht wieder zuströmen, indem er lernt, aus den niedrigsten und alltäglichsten Nöten seines Volkes dessen tiefste Bedürfnisse zu erkennen und so die Wurzel zu finden, aus der allein eine wahrhaft grosse, allumspannende und überschattende Kunst emporwachsen kann."

35. "Sobald diese eben nicht mehr unter dem Wertmassstab der Qualität, sondern der politischen Zweckmässigkeit gestellt," in "Musikpolitik," Die Musikpflege 3, no. 9 (1932): 367. Quoted in Eichhorn (2002), 324. Other key texts by Bekker on this issue include: "Musik und Propaganda," Neue Zürcher Zeitung, Nov. 19, 1933; "Geist unter dem Pferdeschwanz," Pariser Tageblatt 2 (1934); "Die Politisierte Oper," New Yorker Staatszeitung, February 10, 1935.

36. See Bekker, Das Operntheater (1931); the two chapters are entitled "Krise" and "Politik."

37. See ibid., 124, 132. The "inner organic laws" of opera emerged from the music, which Bekker considered the central element of opera. In "Die Opernszene" (1913), he describes music as being one of the three elements of opera, along with scene [Bild] and action [Handlung], that together create an "organic impression" [organische Eindruk], but also for Bekker exist in a hierarchy. The primary element is music, the carrier and mediator of feeling, "Die gefühlsmässige Mittlerin der Empfindungen" (143). The secondary element is the static display of contours and colours on stage. The music is not capable of expressing the entirety of the work alone, and strives to have an impact on the eye as well as the ear. By interacting with these static elements on the stage, music has an impact on the visual as well as the aural impression. It is important for Bekker that the scenic display remains relatively static, in order that the musical expression can move freely (144). Third and last in the hierarchy is the "outer" story or action [äussere Handlung], the dynamic element that connects the scenes and makes obvious the narrative and the development of the plot. The staging and the action, then, serve to make clear the expressive message of the music.

38. Bekker, Das Operntheater, 125.

39. "Zu dieser Freiheit des Theaters rechne ich über alle persönliche Dinge hinaus die Gelöstheit von der Parteipolitik. Wie jeder grosse Betrieb zählt das Theater Angehörige aller Parteien zu seinen Mitgliedern. Von der Bühne her aber sind wir weder Nationalsozialistisch, noch Sozialdemokraten oder Zentrumsleute. Zeigen 
wir Werke, von denen das eine jener, das andere dieser Partei angemessen oder unangemessen ist, so zeigen wir sie nicht aus Parteitendenz, sondern weil sie Dokumente des geistigen und öffentlichen Lebens sind. Jeder mag daraus entnehmen, was ihm zusagt oder missfällt-wir erfüllen nur unsere Pflicht, sie zu zeigen und damit sie zur Diskussion zu stellen" (Letter from the Kasseler Tageblatt to Bekker, December 21, 1926; and Bekker's reply "Was ich der Stadt Kassel für das Jahr 1927 wünsche?" [undated] in Bekker Collection, Folder 32/414).

40. Sie wünschen eine von mir ausgehende programmatische Erklärung (c. May 1931), Bekker Collection, Folder 32/415. See also the book chapter "Das Staatstheater," which Bekker wrote for the 1929 book Wiesbaden: Seine Schönheit und Seine Kultur: "Staatstheater sein heisst Volkstheater sein, Volkstheater nicht im Dienste einer politischen Partei, sondern im Sinne der Zusammenfassung aller schöpferischen Geisteskräfte, des Aufzeigens dieser Kräfte in einer Form, die deutsche Kunst, schöpferische wie nachschaffende, einem einheimischen und fremdländischen Hörerkreis in würdigster Weise vorführt" (Bekker Collection, Folder 56/709, 81).

41. Bekker, "Der Musiklehrer von heute in der öffentlichen Kritik," Deutsche Tonkünstlerzeitung, no. 508, October 5, 1929, 658. Here quoted from Eichhorn, Paul Bekker, 286.

42. "Die Opernszene der Romantik" (1923), Bekker Collection, Folder 46/597, 1-22. The article that is likely to be Bekker's very first publication was entitled "Zur Charakteristik der Stimmen" and was published in Die Musik in 1905. Although mainly a straightforward historical description of the role and development of the different voice types in opera, the last paragraph of this article incidentally points forward, to his later view of the voice as an "organic" element, which reaches beyond mere historical interest and has relevance for the creative artist.

43. Ibid., 3 .

44. Ibid., 4-5. The main aim of the article is to trace the development of opera (analyzing the relationship between musical and scenic elements), and to provide a description of nineteenth-century opera (especially Wagner) based on this development.

45. "Stimme und Gestalt," Musikblätter des Anbruch 6 (1924), and "Die Neue Oper," ibid., 7 (1925).

46. "Stimme und Gestalt," 1.

47. "Die Neue Oper," 12.

48. Ibid., 13

49. Ibid., 15: "In dieser Neuerkennung der Stimme überhaupt aber innerhalb des
Gesamtbereiches der Oper aller Zeiten und Richtungen liegt die Aufgabe der produktiven Empfängnis. Denn die "neue Oper" ist nicht etwas, das wie ein neuer Modeartikel von aussen an uns herantritt, sondern sie ist das, was wir aus der Kraft unserer Anschauung neu sehen und aus uns herausstellen."

50. See, for example, "Stimme und Gestalt," 2.

51. See, for example, ibid., 4, and "Die Neue Oper,"13.

52. "Die singende Menschenstimme ist die Wurzel, aus der die Oper erwachsen ist. Sie ist die Kraft, die die Oper weiterträgt. Sie ist die Macht, die sie immer wieder zur Vollendung führt, je nach der Art, wie das Wesen der Stimme erkannt wird. Aus der Stimme ersteht die Gestalt, sie wird körperlich so erschaubar, wie der Lebenswuchs der Stimme es befiehlt" (Bekker, Wandlungen der Oper [Zürich: Orell Füssli Verlag, 1983], 7).

53. Wandlungen der Oper, 8. Although the chapter "Stimme und Gestalt" shares its title with the earlier article of 1924 (mentioned above), it does not reproduce its content.

54. Ibid., 176.

55. By the time Wandlungen der Oper was published in August 1934, the Nazis had of course already gained power, and Bekker had left Germany for Paris and later New York. For a useful account of the extent to which opera came under political and economic pressure, see Erik Levi, Music in the Third Reich, (London: Macmillan, 1994), 166-95. It is worth noting that Bekker belonged to the few opera administrators who according to Levi defied the increasing conservatism and were "prepared to take risks at a time of great social and political upheaval" (170). In 1932, at the height of both political and economic instability, Wiesbaden saw performances of Weill's Die Bürgschaft (which had been the centre of controversy at its premiere in Berlin just a few days earlier), and a premiere of Ignaz Lilien's Die Grosse Katharina.

56. Bekker, Wandlungen der Oper, vii. These phrases provide yet another manifestation of Bekker's wish to separate politics and music.

57. Ibid., viii.

58. Ibid., viii: "Aus solcher unlösbaren Bindung der Oper an die menschliche Natur ist Vergangenes zu verstehen, Gegenwärtiges zu berurteilen, Künftiges zu erahnen. Dringt diese Erkenntnis durch, so mag sie vom Einzelgebiet der Oper aus dazu helfen, die Achtung vor dem Menschen selbst zu festigen, indem sie zeigt, dass Kunst niemals Gesamtheitserzeugnis gleichviel welcher weltanschaulicher Kollektive, sondern stets nur da möglich war, ist und sein wird, wo der Mensch als solcher möglich ist." 